\title{
Pandemia COVID-19. Planificación del área quirúrgica e implementación de nuevo listado de verificación para cirugía segura en un hospital universitario COVID-19 pandemic. Planning for surgery and implementation of a novel surgical safety checklist in an university hospital
}

\author{
Ariel P. Ramos (D), Roberto de Anton (D), Eduardo B. Arribalzaga (D), Luis E. Sarotto (h)
}

Hospital de Clínicas José de San Martín, Universidad de Buenos Aires, Argentina.

Los autores declaran no tener conflictos de interés.

Conflicts of interest None declared.

Correspondencia Correspondence:

Ariel P. Ramos E-mail: arielpabloramos@gmail. com

\section{RESUMEN}

Antecedentes: la existencia de la pandemia infectocontagiosa COVID-19 puede afectar a los equipos quirúrgicos y pacientes.

Objetivo: describir los cambios introducidos en la estructura y los procesos de una planta quirúrgica a fin de adaptarla a la atención segura de pacientes positivos y sospechosos, así como los resultados iniciales de su implementación.

Material y métodos: se realizó un estudio prospectivo, descriptivo, observacional entre el $1^{\circ}$ de abril y el 31 de mayo de 2020. Fueron registrados los cambios estructurales y en los procesos de funcionamiento adaptados a la atención de pacientes sospechosos y COVID-19 positivos, así como las actividades desarrolladas en dicha área.

Resultados: se registró una disminución en el número de cirugías programadas y de urgencia en el período. Entre 173 cirugías de urgencia, hubo 17 pacientes sospechosos (9,8\%) y 3 positivos (1,7\%), confirmados por la prueba de PCR. No hubo pacientes con resultados ni sospechosos ni confirmados en 136 cirugías programadas. La adhesión al cumplimiento de la lista de verificación fue del 100\%. No se registraron contagios entre el personal actuante.

Conclusiones: los cambios implementados en la planta quirúrgica permitieron la atención adecuada de pacientes tanto sospechosos como confirmados durante el período, con completa adhesión a las recomendaciones y disminución en el riesgo de transmisión de la enfermedad para dar seguridad a los pacientes y al equipo de salud.

Palabras clave: COVID-19, cirugía segura, área quirúrgica.

\section{ABSTRACT}

Background: COVID-19 pandemic may affect the surgical teams and patients.

Objective: The aim of this report was to describe the changes introduced in the structure and processes of a surgical facility for the safe care of suspected and positive COVID-19 patients, and to describe the initial results of their implementation.

Material and methods: We conducted a prospective, descriptive and observational study between April 1 and May 31, 2020. The structural changes and the modifications introduced in the functioning processes within the surgical area of a university hospital adapted to the care of suspected and positive COVID-19 patients, and the activities developed in such area were documented.

Results: There was a reduction in the number of scheduled and emergency surgeries performed during the study period. Of the 173 emergency surgeries, 17 (9.8\%) were suspected cases and $3(1.7 \%)$ resulted positive COVID-19 patients confirmed by PCR tests. None of the 136 patients undergoing scheduled surgeries were suspected or confirmed cases. Compliance with the checklist was $100 \%$. There were no infections among the personnel working in the facility.

Conclusions: The changes implemented in the surgical facility allowed for adequate care of suspected and confirmed COVID-19 patients during the period, with complete adherence to recommendations and reduced risk of disease transmission in order to provide safety to patients and the health care team.

Keywords: COVID-19, safe surgery, operating room.
Recibido | Received 08-06-20 Aceptado | Accepted 18-06-20
ID ORCID: Ariel P. Ramos, 0000-0002-8653-936X; Roberto de Anton, 0000-0002-2348-228X; Eduardo B. Arribalzaga, 0000-0002-8735-7912; Luis E. Sarotto, 0000-0002-7480-7144. 


\section{Introducción}

La enfermedad viral infectocontagiosa por coronavirus 2019 (COVID-19) fue detectada por primera vez en la ciudad de Wuhan (China) en diciembre de 2019; se propaga rápidamente, con brotes epidémicos que pueden crecer a un ritmo exponencial ${ }^{1}, \mathrm{y}$ es muy probable que pacientes con confirmación/sospecha de infección precisen una intervención quirúrgica en algún momento ${ }^{2}$.

En la actualidad no existen terapias o vacunas que traten o prevengan la infección y se trabaja con urgencia para coordinar el ágil desarrollo de contramedidas médicas ${ }^{3}$, dado el elevado índice de propagación y su virulencia (la gravedad de los casos) ${ }^{4}$.

En razón de la afectación de esta enfermedad también a pacientes quirúrgicos y al equipo de salud, el objetivo del presente informe fue describir los cambios introducidos en la estructura y los procesos de una planta quirúrgica a fin de adaptarla a la atención segura de estos pacientes, así como los resultados iniciales de su implementación.

\section{Material y métodos}

Se realizó un estudio prospectivo, descriptivo, observacional entre el $1^{\circ}$ de abril y el 31 de mayo de 2020.

Fueron registrados los cambios introducidos en la estructura y en los procesos de funcionamiento en el área quirúrgica de un Hospital Universitario adaptada a la atención de pacientes sospechosos y COVID-19 positivos, así como las actividades desarrolladas en dicha área.

Se tomaron los recaudos éticos según las recomendaciones de Helsinki y Tokio y sus modificaciones posteriores. Los datos clínicos fueron protegidos de modo que no se pueda identificar a quién pertenecen ni sean accesibles a personas no comprometidas con el secreto profesional. Todos los pacientes firmaron el consentimiento informado para las cirugías aprobado por el Comité de Ética de la institución.

\section{Resultados}

Se planificó un circuito para el traslado de los pacientes infectados o sospechosos desde el área de aislamiento correspondiente al área quirúrgica designada (Fig. 1). El quirófano 17 fue el utilizado exclusivamente y su acceso fue señalizado en todo su recorrido (Fig. 2).

Se describe el equipamiento destinado a dicho quirófano (Tabla 1) y las funciones que se llevan a cabo en la antesala de entrada (lavabo) y la antesala de salida.

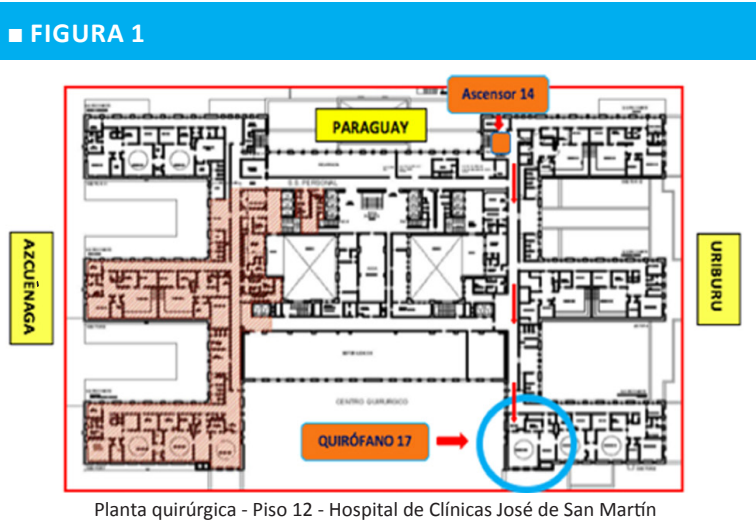

Diagrama de la planta quirúrgica. Se señala la ubicación del quirófano exclusivo para pacientes con COVID-19 y la vía de acceso.

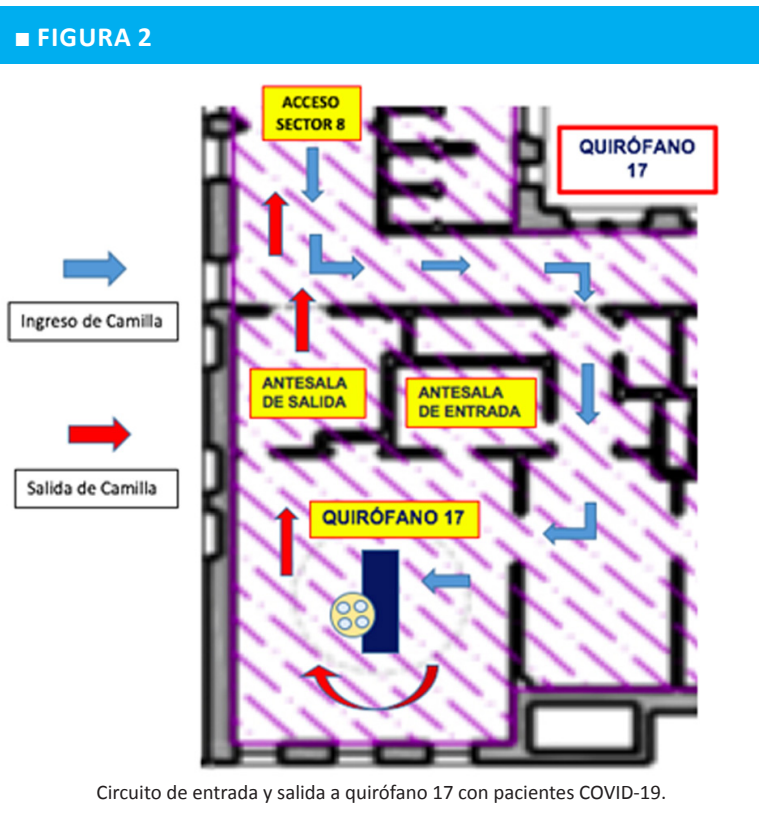

Diagrama del quirófano exclusivo para COVID-19 con el sentido de la circulación.

\section{- TABLA 1}

Equipamiento de uso exclusivo en el quirófano 17

Mesa de anestesia y monitores

Desfibrilador

Bomba de infusión de medicamentos

Consola de electrobisturí

Camilla y accesorios enfundados

$\mathrm{Pie} / \mathrm{s}$ de suero

Lebrillos con bolsas rojas

Batea con tapa para Instrumental

Batea para anestesia (queda junto a la mesa)

Manoplas

Mesa de transporte

Equipamiento adicional que se solicita Laparoscopia, Radiología, etc.

Vitrinas vacías y con puertas cerradas 
Antesala de entrada y funciones de la instrumentadora/ enfermera circulante externa (CE)

La CE se encargó de la preparación del material necesario para la cirugía (elementos quirúrgicos y de anestesiología). Allí se completó el listado de verificación de cirugía segura propuesto por la $\mathrm{OMS}^{5}$, los certificados de implante, etc. La CE no ingresó en el quirófano una vez comenzada la cirugía ${ }^{2}$.

La CE fue la encargada de supervisar la colocación de equipo de protección personal $(E P P)^{6}$ y del cumplimiento de las normas de seguridad por parte del resto del equipo:

- No ingresar en quirófano objetos personales ni celulares.

- Ambo dentro del pantalón.

- Calzado cerrado.

- Doble par de botas.

- Colocar barbijo N95 (ajustado a anatomía personal).

- Cofia o escafandra descartable por encima de la cofia de tela, o doble cofia descartable.

- Barbijo quirúrgico por encima de N95.

- Antiparras.

- Pantalla facial.

- Lavado quirúrgico de manos previo al ingreso en el quirófano.
Se completó el EPP ya dentro de quirófano, asistido por la instrumentadora aséptica y supervisado por la instrumentadora/enfermera circulante interna $(\mathrm{Cl})^{7}$ :

- Colocar primer par de guantes.

- Camisolín hidrorrepelente atado.

- Segundo par de guantes (por encima del puño del camisolín).

- La antesala de salida fue provista de:

- Bateas rotuladas (para EPP del equipo quirúrgico).

- Dosificadores con hipoclorito de sodio al 1\%, ácido peracético o alcohol.

- Un recipiente con tapa para descartar la ropa utilizada.

- Vitrina cerrada con ropa descartable para cambiarse antes de circular por la planta nuevamente o para trasladar a un paciente.

- La CE verificó las acciones de salida y del equipo quirúrgico, ya que fue la responsable de completar y firmar la Check-list COVID-19 (Fig. 3).

Según las recomendaciones actuales, el tipo de EPP para utilizar en cada instancia de atención se clasifica por niveles ${ }^{8}$ (Tabla 2).

Se implementó el listado de verificación o Check-list COVID-199, en pacientes sospechosos o confirmados por rtPCR para SARS-CoV-2 con los criterios del Ministerio de Salud de la Nación para definir caso

\section{- FIGURA 3}

LISTADO DE VERIFICACIÓN DE SEGURIDAD EN CIRUGÍA - PANDEMIA COVID- 19

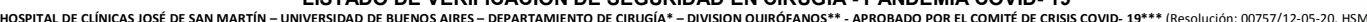
FECHA:...................../2020 PACIENTE CON SOSPECHA DE COVID - 19. PACIENTE CON COVID - 19 POSITIVO.

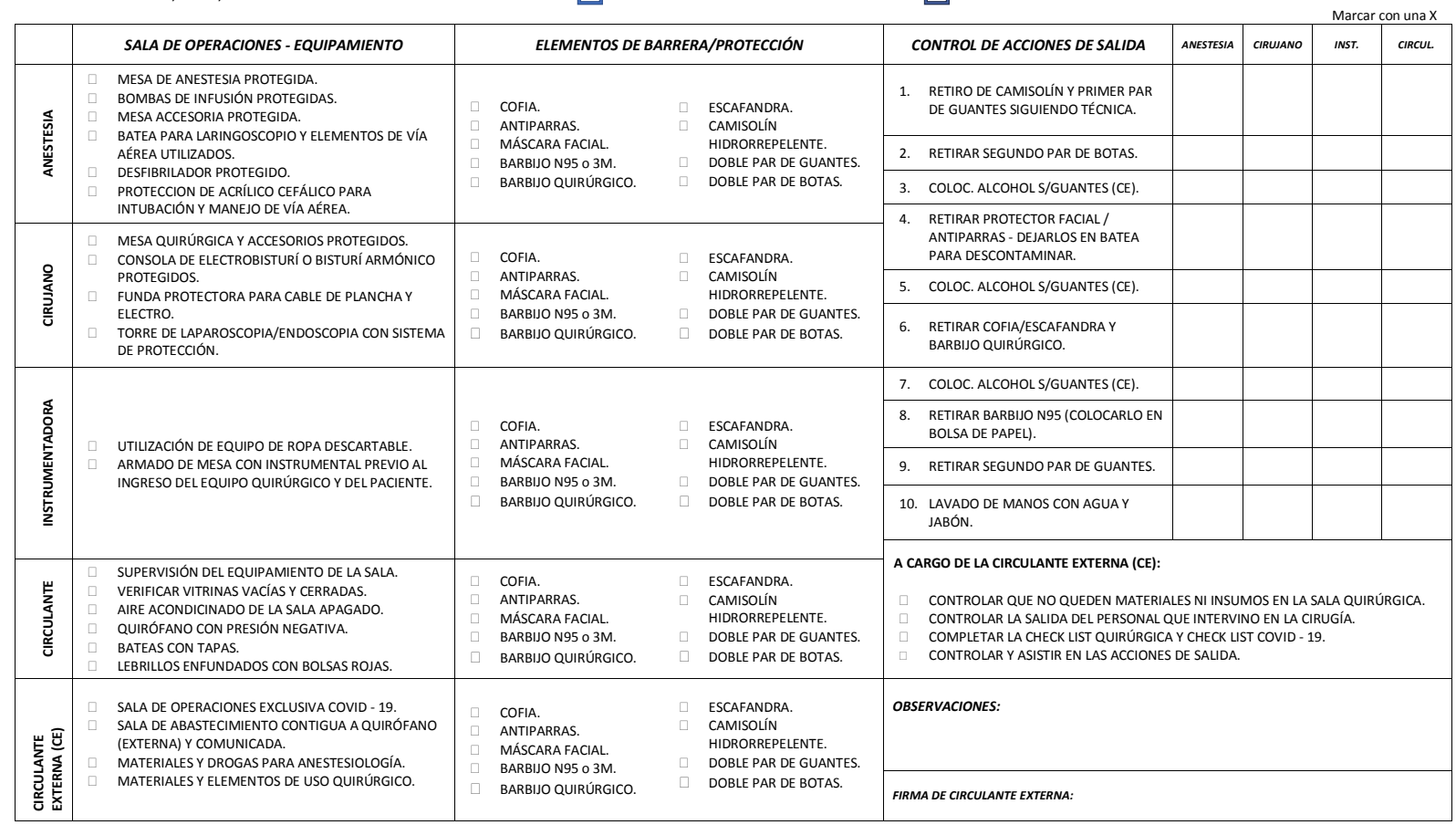

AUTORES: **DR. RAMOS ARIIEL - JEFE DIVIIIÓN QUIRÓFANOS CENTRALES; DR DE ANTÓN ROBERTO - JEFE QUIRÓFANOS PERIFÉRICOS; LIC. DELOR STELLA M - SUPERVISORA DE QUIRÓFANOS;; LLC. FRAIZ VIVIANA - SUPERVISORA DE QUIRÓFANOS;

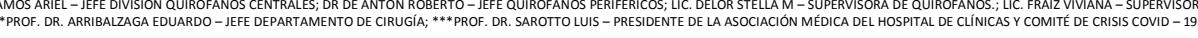




\section{- TABLA 2}

Niveles de EPP según el riesgo en la exposición al contagio

EPP Nivel 1:

Sin contacto con pacientes y sin riesgo de exposición a fluidos corporales

Antiparras

Cofia

Barbijo quirúrgico común

Camisolín contacto

Guantes látex

Botas

EPP Nivel 2:

Contacto con pacientes y riesgo de exposición a fluidos corporales

Antiparras - Máscara facial

Cofia

Barbijo quirúrgico común

Camisolín hidrorrepelente

Guantes látex

Botas

EPP Nivel 3:

Se realizan maniobras con aerosoles

Máscara facial

Antiparras

Cofia - Escafandra

Barbijo N95

Camisolín hidrorrepelente

Guantes látex

Botas

sospechoso y positivo ${ }^{10}$. Este listado presentado en el Comité de Crisis del Hospital Universitario fue aprobado por Resolución Ejecutiva de la Dirección del Hospital 00757/12-05-20 (Fig. 3).

El primer paciente confirmado positivo para infección por coronavirus COVID-19 se internó el 17 de marzo de 2020. Desde ese comienzo se internaron 340 casos sospechosos (de ellos, 238 casos fueron dados de alta como negativos), 75 confirmados como positivos (38 ya de alta) y hubo 7 óbitos en pacientes positivos ${ }^{11}$.

En el período Abril/Mayo 2020 hubo un total de 309 cirugías (136 programadas y 173 urgencias). En todos los casos se aplicó el Protocolo de Quirófano aprobado por el Comité de Crisis para potencial paciente infectado ${ }^{9}$.

No hubo pacientes programados con resultados sospechosos/confirmados (136 de 309, 44\%). De los operados por urgencias (173 de $309,56 \%$ ) fueron sospechosos $17 / 173(9,8 \%)$ y $3 / 173(1,7 \%)$ resultaron positivos confirmados por la prueba de PCR ( 2 cesáreas y una traqueostomía, esta última en paciente en Unidad de Terapia Intensiva). No hubo accidentes ni faltantes de EPP para los equipos quirúrgicos actuantes.

En todos los casos fueron llenados satisfactoriamente los listados de verificación empleados. No se registraron contagios entre el personal actuante en la planta durante el período analizado.

Al comparar la actividad en Quirófanos Centrales para Cirugías Programadas y Urgencias entre Abril/ Mayo 2019 y el mismo período de 2020 se encontró una marcada reducción tanto en el número de cirugías programadas como electivas, siguiendo las recomendaciones adecuadas a la pandemia (Tabla 3 ).

\section{Discusión}

La información sobre esta enfermedad infectocontagiosa está permanentemente en revisión y actualización con una dinámica inusual por su grado de contagio. Debido a su crecimiento exponencial, numerosos pacientes confirmados como positivos o con sospecha de enfermedad pueden requerir un tratamiento quirúrgico electivo inaplazable o urgente. Las actuales recomendaciones sugieren limitar el número de cirugías programadas, incluso en pacientes oncológicos postergar/aplazar aquellos casos que no afectan su cuadro clínico evolutivo y solo intervenir aquellos imprescindibles portadores de neoplasias oclusivas, infectadas o hemorrágicas. No obstante, cada caso debe ser analizado cuidadosamente ${ }^{2}$. En el Hospital se redujo en casi un $80 \%$ la programación de cirugías según las recomendaciones actuales recibidas y no hubo pacientes programados con resultados sospechosos/confirmados (136 de 309, 44\%).

Entre Abril/Mayo de 2020 se operaron un total de 309 pacientes (dos tercios menos que en igual período del año anterior): de ellos solo 17 (9,8\%) fueron sospechosos y $3(1,7 \%)$ positivos confirmados por la prueba de PCR y todos operados de urgencia. A estos se les realizó previamente una evaluación de sospecha de COVID-19 con el cuestionario pertinente, tomografía computarizada de tórax o, en caso de imposibilidad, radiografía de tórax ${ }^{13}$. Si es posible diferir la cirugía unas horas sin comprometer la evolución del paciente, se debe evaluar la necesidad de realizar una prueba de PCR según antecedentes y el tipo de procedimiento, pero es necesario recordar que las cirugías de emergencia no deben retrasarse por realizar un estudio de $\mathrm{PCR}^{2}$.

En el área quirúrgica del Hospital se realizaron cambios en la estructura de quirófanos y en la circulación de los pacientes, a fin de disminuir la exposición entre pacientes no afectados y aquellos sospechosos/ positivos, y disminuir así el riesgo de transmisión de la enfermedad y garantizar la seguridad del equipo quirúrgico y principalmente de los pacientes ${ }^{14}$.

\section{TABLA 3}

Comparación de cantidad de cirugías realizadas en el mismo período en 2019 y 2020.

\begin{tabular}{lccc}
\multicolumn{1}{c}{ Período } & $\begin{array}{c}\text { Abril/Mayo } \\
2019\end{array}$ & $\begin{array}{c}\text { Abril/Mayo } \\
2020\end{array}$ & $\begin{array}{c}\text { Porcentaje } \\
\text { comparativo } \\
(\%)\end{array}$ \\
\hline Urgencias & 331 & 173 & 52,2 \\
Programadas & 611 & 136 & 22,2 \\
Total & 942 & 309 & 32,8
\end{tabular}


Fue necesaria la comunicación previa del cirujano con el área quirúrgica para informar el procedimiento que iba a realizar y de esa forma preparar los insumos y materiales específicos antes de la llegada del paciente. Los materiales quedaron en la antesala del quirófano designado para COVID-19.

Es importante señalar que las intervenciones en pacientes sospechosos o positivos sean realizadas siempre por personal capacitado y con experiencia. Dicho personal debe tener el conocimiento de las medidas de prevención de transmisión y de circulación en área restringida, uso adecuado de los EPP y participar previamente en los protocolos de simulacro para reducir el riesgo de transmisión de enfermedad. Por otra parte, la experiencia es indispensable para acortar los tiempos del procedimiento y disminuir la exposición de todo el equipo quirúrgico.

A tal fin es útil la formación teórico-práctica con realización de simulacros de protocolos preestablecidos. En la institución, cotidianamente se los lleva a cabo con todos los que prestan servicios en el área quirúrgica (personal médico y no médico).

En un paciente confirmado positivo se utiliza el equipo de protección personal de más alto nivel (Nivel $3)^{6}$. Aun en casos no confirmados pero sospechosos, en el actual contexto de pandemia, se asume que todos los pacientes son positivos y se toman las mismas medidas de protección para evitar una exposición innecesaria del personal ${ }^{2,8}$. Los EPP cubren totalmente la piel, especialmente las zonas corporales de alto riesgo como orificios nasales, boca y ojos. En las intervenciones quirúrgicas se pueden producir aerosoles, por lo cual los EPP deben proteger esta particular vía de contagio ${ }^{6}$.

Antes de ingresar el paciente a la planta quirúrgica, las dos instrumentadoras asignadas (instrumentadora aséptica y circulante interna) comienzan con el armado de la mesa operatoria. Una vez preparada, se solicita enviar el paciente al quirófano establecido y utilizar en lo posible material descartable ${ }^{2}$.

El enfermo ingresa en quirófano por el circuito establecido (véase Fig. 1) con barbijo quirúrgico, cofia, camisolín y guantes, lo que es supervisado por la CE. El residente/técnico de anestesia asiste al anestesió- logo en la intubación orotraqueal del paciente, y con el paciente ventilado se habilita el ingreso del equipo quirúrgico para comenzar la cirugía. Las puertas deben mantenerse cerradas en todo momento y limitarse al máximo el número de profesionales que se encuentran en el interior del quirófano y sus movimientos, para reducir el riesgo de contaminación².

Finalizada la cirugía y cuando el paciente está en condiciones de trasladarse, se llama al camillero. Si requiere traslado a Unidad Cerrada (Terapia Intensiva o Unidad Coronaria), el anestesiólogo retirará su camisolín, guantes y botas en la antesala de salida de quirófano bajo la supervisión y asistencia de la CE y acompañará al paciente con un nuevo EPP.

La CE será la encargada de controlar las acciones de salida del equipo quirúrgico y, a tal fin, se diseñó e implementó un nuevo listado de verificación de cirugía segura asociado a un paciente potencialmente infectado por el coronavirus, que no pretende reemplazar ni al propuesto por la $\mathrm{OMS}^{5}$, ni a la adaptación utilizada desde el año 2010 en los quirófanos de la institución ${ }^{14}$, sino ser un agregado al reverso de este para facilitar su uso, con un menor número de formularios y adaptado a la situación actual ${ }^{9}$.

Al terminar la cirugía se realiza una limpieza terminal de la sala de operaciones enfocada en las superficies planas y de apoyo. Los desinfectantes aprobados para eliminar virus son hipoclorito de sodio $u$ otros clorados, alcoholes, compuestos de amonio cuaternario y peróxido de hidrógeno acelerado ${ }^{15}$. El personal de limpieza realiza su tarea con EPP adecuado (Nivel 2) ${ }^{2}$. Es recomendable que dicho personal esté entrenado y participe en los protocolos de simulacro que se realizan cotidianamente en la Planta Quirúrgica. Finalizado el procedimiento, una vez pasada una hora, se puede volver a usar el quirófano.

Esta enfermedad, actualmente con gran circulación del virus en la comunidad del área metropolitana de Buenos Aires (AMBA) ${ }^{16}$, demanda adoptar medidas especiales para disminuir la posibilidad de contagio entre pacientes, la exposición del personal sanitario y el desarrollo de complicaciones posoperatorias atribuibles a esta pandemia.

\section{Introduction}

Coronavirus disease 2019 (COVID-19) was first detected in the city of Wuhan (China) in December 2019 and has spread quickly, with epidemic outbreaks that can grow at an exponential rate ${ }^{1}$, and it is very likely that patients with confirmed or suspected infection will require surgical intervention at some point ${ }^{2}$.
There are currently no therapies or vaccines to treat or prevent the infection and intensive efforts are being made to coordinate the rapid development of medical countermeasures ${ }^{3}$, given its high spreading and virulence rates (severe illness among confirmed (ases) $)^{4}$.

Because this disease also affects surgical patients and the healthcare team, the aim of this report 
was to describe the changes introduced in the structure and processes of a surgical facility for the safe care of these patients, and to describe the initial results of their implementation.

\section{Material and methods}

We conducted a prospective, descriptive and observational study between April 1 and May 31, 2020.

The structural changes and the modifications introduced in the functioning processes within the surgical area of a university hospital adapted to the care of suspected and positive COVID-19 patients, and the activities developed in such area were documented.

The study was conducted following the ethical principles of the Declaration of Helsinki and revised in Tokyo. The clinical data were protected so as not to identify to whom they belong and not to be accessible to persons not bound by professional secrecy. All the patients signed an informed consent form approved by the Committee on Ethics of the institution.

Results

A transportation route was designed to transport COVID-19 positive or suspected patients from the isolation ward to the designated surgical area (Fig. 1). The operating room (OR) 17 was dedicated for these patients and signs were posted all along the route to the OR 17 (Fig. 2).

Table 1 describes the equipment designated for this OR and the functions carried out in the entrance hall (hand wash basin) and exit lobby.

\section{Entrance hall and functions of the circulating nurse:}

The circulating nurse was responsible for preparing the necessary equipment for the surgery (surgical and anesthesiology elements). The WHO Surgical Safety Checklist $^{5}$ and documentation of implants were completed there. The circulating nurse did not enter the OR once surgery had begun².

The circulating nurse was responsible for supervising proper donning of personal protective equipment (PPE) ${ }^{6}$ and compliance with safety standards by the rest of the team:

- No personal items or mobiles inside the OR.

- Top of the scrub on the inside of the pant.

- Closed shoes.

- Two pairs of shoe covers.

- N95 respirator (adjusted to personal anatomy).

- Scrub hat or hood over the cloth hat or double disposable hat.

\section{- FIGURE 1}

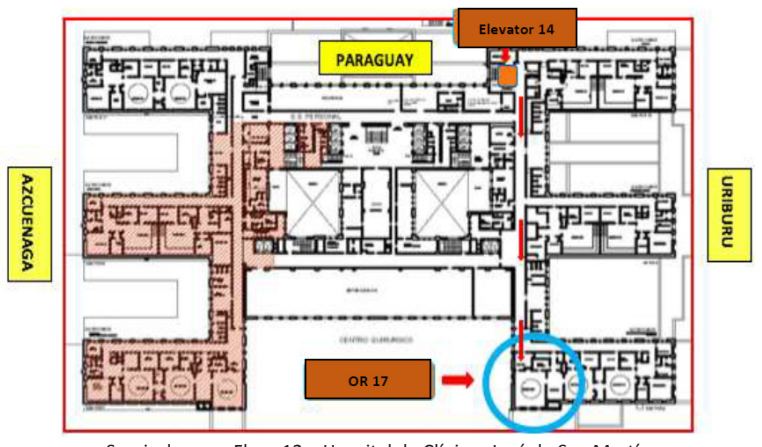

Overview of the surgical area for COVID-19 patients

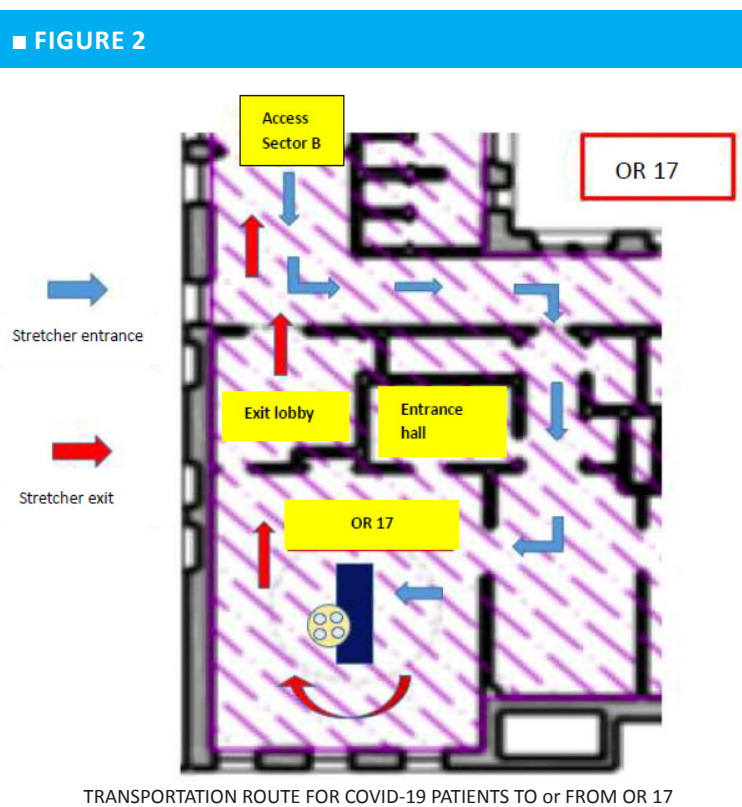

Overview of the operating room dedicated for COVID-19 patients and route of access.

\section{TABLE 1}

Equipment for exclusive use in the operating room 17.

Anesthesia cart and monitors.

Defibrillator

Infusion pump for medications

Electrosurgical unit

Covered stretcher and accessories

Drip stand/s

Basins with red bags

Tray with lid for instruments

Anesthesia tray (next to the cart)

Mittens

Mobile cart

Additional equipment required (laparoscopy, radiology, etc.)

Empty and closed cabinets. 
- Surgical mask cover over the N95 respirator.

- Goggles.

- Face shield.

- Surgical hand scrub before entering the OR.

The PPE was completed inside the OR with the help of the scrub nurse and supervised by a second scrub person ${ }^{7}$ :

- Donning the first pair of gloves.

- Donning and fastening a fluid-resistant gown.

- Second pair of gloves flipped up and over the cuff of the gown.

- The exit lobby was equipped with:

- Labeled trays (for the PPE of the surgical team).

- Dispensers with $1 \%$ sodium hypochlorite, peracetic acid or alcohol.

- A container with a lid for disposal of worn clothing.

- Closed cabinet with disposable clothing to wear before moving around the surgical area again or transferring a patient.

- The circulating nurse verified the actions of the surgical team before leaving the OR and was responsible for completing and signing the COVID-19 checklist (Fig. 3).

According to the current recommendations, the use of PPE depends on the level of care ${ }^{8}$ (Table 2).

The Covid-199 ${ }^{9}$ checklist was implemented in patients with suspected or confirmed disease by rtPCR for SARS-CoV-2 with the criteria established by the National Ministry of Health to define suspected and positive $\operatorname{cases}^{10}$. This checklist was presented to the Crisis Committee of the University Hospital and was approved (Resolución Ejecutiva de la Dirección del Hospital 00757/12-05-20) (Fig. 3).

The first confirmed COVID-19 patient was hospitalized on March 17, 2020. Since then, 340 suspected cases were admitted (238 were discharged as negative cases), 75 were confirmed cases (38 have already been discharged) and 7 positive patients died ${ }^{11}$. In the study period, 309 surgeries were performed (136 scheduled surgeries and 173 emergency procedures). The OR protocol approved by the Crisis Committee for potentially infected patients was applied in all the cases ${ }^{9}$.

None of the patients undergoing scheduled surgeries had suspected or confirmed COVID-19 $(136 / 309,44 \%)$. Of those patients undergoing emergency procedures (173/309, 56\%) 17 (9.8\%) were suspected cases and $3(1.7 \%)$ resulted positive COVID-19 patients confirmed by PCR tests (two cesarean sections and one tracheostomy in a patient hospitalized in the intensive care unit). There were no accidents or PPE shortage for the surgical team.

\section{- FIGURE 3}

SURGICAL SAFETY CHECKLIST - COVID-19 PANDEMIC

DATE:...................../2020 SUSPECTED COVID - 19 PATIENT $\square \quad$ POSITIVE COVID - 19 PATIENT

\begin{tabular}{|c|c|c|c|c|c|c|c|c|c|}
\hline & \multicolumn{3}{|c|}{ Please $\mathrm{X}$ mark as applicable } \\
\hline & OR - EQUIPMENT & & BARRIER/PROT & TIVE EQUIPMENT & CHECK EXIT ACTIONS & ANESTHESIA & SURGEON & \begin{tabular}{l|l} 
SCRUB \\
NURSE
\end{tabular} & $\begin{array}{c}\text { CIRC. } \\
\text { NURSE }\end{array}$ \\
\hline \multirow{3}{*}{ 感 } & \multirow{3}{*}{$\begin{array}{l}\text { ANESTHESIA CART PROTECTED. } \\
\text { INFUSION PUMPS PROTECTED. } \\
\text { ACCESORY CART PROTECTED. } \\
\text { TRAY FOR LARYNGOSCOPE AND AIRWAY ELEMENTS } \\
\text { USED. } \\
\text { DEFIBRILAATOR PROTECTED. } \\
\text { INTUBATION BOX PROTECTED. }\end{array}$} & \multirow{3}{*}{$\begin{array}{l}\square \\
\square \\
\square \\
\square \\
\square\end{array}$} & \multirow{3}{*}{$\begin{array}{l}\text { SCRUB HAT. } \\
\text { GOGGLES. } \\
\text { FACE SHIELD. } \\
\text { N95 or } 3 \text { M RESPIRATOR. } \\
\text { SURGICAL MASK. }\end{array}$} & \multirow{3}{*}{$\begin{array}{l}\text { HOOD. } \\
\text { FLUID-RESISTANT GOWN. } \\
\text { DOUBLE PAIR OF GLOVES. } \\
\text { DOUBLE PAIR OF SHOE } \\
\text { COVERS. }\end{array}$} & $\begin{array}{l}\text { 1. REMOVE GOWN AND FIRST PAIR OF } \\
\text { GLOVES FOLLOWING TECHNIQUE. }\end{array}$ & & & & \\
\hline & & & & & $\begin{array}{l}\text { 2. REMOVE SECOND PAIR OF SHOE } \\
\text { COVERS }\end{array}$ & & & & \\
\hline & & & & & 3. PLACE ALCOHOL ON GLOVES (CN) & & & & \\
\hline \multirow{3}{*}{ 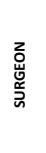 } & \multirow{3}{*}{$\begin{array}{l}\square \text { OR TABLE AND ACCESSORIES PROTECTED. } \\
\text { ELECTROSURGICAL UNIT OR HARMONIC SCALPEL } \\
\text { PROTECTED. } \\
\text { PROTECTIVE COVER FOR PLATE CABLE AND } \\
\text { ELECTRODE. } \\
\text { TOWER FOR LAPAROSCOPY/ENDOSCOPY WITH } \\
\text { PROTECTIVE SYSTEM. }\end{array}$} & \multirow{3}{*}{$\begin{array}{l}\square \\
\square \\
\square \\
\square \\
\square\end{array}$} & \multirow{3}{*}{$\begin{array}{l}\text { SCRUB HAT. } \\
\text { GOGGLE. } \\
\text { FACE SHIELD. } \\
\text { N95 or 3M RESPIRATOR. } \\
\text { SURGICAL MASK. }\end{array}$} & \multirow{3}{*}{$\begin{array}{l}\square \text { HOOD. } \\
\text { FLUID-RESISTANT GOWN. } \\
\text { DOUBLE PAIR OF GLOVES. } \\
\square \\
\text { DOUBLE PAIR OF SHOE } \\
\text { COVERS. }\end{array}$} & $\begin{array}{l}\text { 4. REMOVE FACIAL SHIELD/ GOGGLES. } \\
\text { LEAVE THEM IN TRAY FOR } \\
\text { DISINFECTION }\end{array}$ & & & & \\
\hline & & & & & 5. PLACE ALCOHOL ON GLOVES (CN) & & & & \\
\hline & & & & & $\begin{array}{l}\text { 6. REMOVE SCRUB HAT/HOOD AND } \\
\text { SURGICAL MASK. }\end{array}$ & & & & \\
\hline \multirow{4}{*}{ 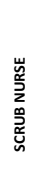 } & \multirow{4}{*}{$\begin{array}{l}\text { USE OF DISPOSABLE CLOTHING. } \\
\text { SET UP THE INSTRUMENT TABLE BEFORE THE } \\
\text { SURGICAL TEAM AND PATIENT ENTER THE OR. }\end{array}$} & \multirow{4}{*}{$\begin{array}{l}\square \\
\square \\
\square \\
\square \\
\square\end{array}$} & \multirow{4}{*}{$\begin{array}{l}\text { SCRUB HAT. } \\
\text { GOGGLES. } \\
\text { FACE SHIELD. } \\
\text { N95 or } 3 \text { M RESPIRATOR. } \\
\text { SURGICAL MASK. }\end{array}$} & \multirow{4}{*}{$\begin{array}{l}\square \text { HOOD. } \\
\text { FLUID-RESISTANT GOWN. } \\
\text { DOUBLE PAIR OF GLOVES. } \\
\square \text { DOUBLE PAIR OF SHOE } \\
\text { COVERS. }\end{array}$} & 7. PLACE ALCOHOL ON GLOVES (CN) & & & & \\
\hline & & & & & $\begin{array}{l}\text { 8. REMOVE N95 RESPIRATOR (PLACE IT } \\
\text { IN A PAPER BAG). }\end{array}$ & & & & \\
\hline & & & & & 9. REMOVE SECOND PAIR OF GLOVES. & & & & \\
\hline & & & & & $\begin{array}{l}\text { 10. HAND WASHING WITH WATER AND } \\
\text { SOAP. }\end{array}$ & & & & \\
\hline 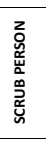 & $\begin{array}{l}\text { SUPERVISE OR EQUIPMENT } \\
\text { VERIFY EMPTY AND CLOSED CABINET. } \\
\text { CHECK AR CONDIIIONING SYSTEM IS TURNED OFF. } \\
\text { OR WITH NEGATIVE PRESSURE. } \\
\text { TRAYS WITH LDS. } \\
\text { BASINS SHEATHED IN RED BAGS. } \\
\end{array}$ & 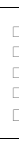 & $\begin{array}{l}\text { SCRUB HAT. } \\
\text { GOGGLES. } \\
\text { FACE SHIELD. } \\
\text { N95 or 3M RESPIRATOR. } \\
\text { SURGICAL MASK. }\end{array}$ & $\begin{array}{l}\square \text { HOOD. } \\
\square \text { FLUID-RESISTANT GOWN. } \\
\square \text { DOUBLE PAIR OF GLOVES. } \\
\square \text { DOUBLE PAIR OF SHOE } \\
\text { COVERS. }\end{array}$ & \multicolumn{5}{|l|}{$\begin{array}{l}\square \quad \text { VERIFY THAT NO MATERIALS OR SUPPL } \\
\square \quad \text { VERIFY THE EXIT OF THE SURGICAL STA } \\
\quad \text { COMPLETE TESURGIIAL SAETY CHEC } \\
\text { CHECK AND ASSIST EXIT ACTIONS. }\end{array}$} \\
\hline \multirow{2}{*}{ 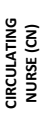 } & \multirow[t]{2}{*}{$\begin{array}{l}\square \text { OR DEDICATED TO COVID-19 PATIENTS. } \\
\text { EQUIPMENT AND SUPPLIES ROOM NEXT TO AND } \\
\text { COMMUNICATED WITH THE OR } \\
\text { ANESTHESIA EQUIPMENT AND DRUGS. } \\
\text { SURGICAL MATERIALS AND ELEMENTS. }\end{array}$} & \multirow{2}{*}{$\begin{array}{l}\square \\
\square \\
\square \\
\square \\
\square\end{array}$} & \multirow{2}{*}{$\begin{array}{l}\text { SCRUB HAT. } \\
\text { GOGGLES. } \\
\text { FACE SHIELD. } \\
\text { N95 or 3M RESPIRATOR. } \\
\text { SURGICAL MASK. }\end{array}$} & \multirow{2}{*}{$\begin{array}{ll}\square & \text { HOOD. } \\
& \text { FLUID-RESISTANT GOWN. } \\
& \text { DOUBLE PAIR OF GLOVES. } \\
\square & \text { DOUBLE PAIR OF SHOE } \\
\text { COVERS. }\end{array}$} & \multicolumn{5}{|l|}{ OBSERVATIONS: } \\
\hline & & & & & CIRCULATING NURSE SIGNATURE: & & & & \\
\hline
\end{tabular}

AUTHORS: **DR. RAMOS ARIEL - CHIEF, CENTRAL OPERATING ROOMS; DR DE ANTÓN ROBERTO - CHIEF, PERIPHERAL OPERATING ROOMS; LIC. DELOR STELLA M - OPERATING ROOM SUPERVISOR;; LLC. FRAIZ VIVIANA - OPERATING ROOM SUPERVISOR; 
The checklists were properly filled in all the cases. There were no infections among the personnel working in the facility during the period analyzed.

When the number of scheduled and emergency surgeries performed between April and May 2019 were compared with the same period in 2020, there was a significant reduction in both types of surgeries, following the recommendations adopted during the pandemic (Table 3).

\section{Discussion}

The information on this infectious disease is in permanent revision and is updated with an unusual dynamic due to its high transmissibility. Given its exponential growth, many COVID-19 positive or

\section{- TABLE 2}

PPE levels according to the risk of exposure

PPE level 1:

No contact with patients and no risk of exposure to body fluids

Goggles.

Scrub hat

Surgical mask

Contact gown

Latex gloves

Shoe covers

PPE level 2:

Contact with patients and risk of exposure to body fluids

Goggles - Face shield

Scrub hat

Surgical mask

Fluid-resistant gown

Latex gloves

Shoe covers

PPE Level 3:

Aerosol generating procedures

Face shield

Goggles.

Scrub hat - Hood

N95 respirator

Fluid-resistant gown

Latex gloves

Shoe covers

\section{- TABLE 3}

Comparison of the number of surgeries performed over the sam period in 2019 and 2020

\begin{tabular}{lccc|}
\multicolumn{1}{c}{ Period } & $\begin{array}{c}\text { April-May } \\
2019\end{array}$ & $\begin{array}{c}\text { April-May } \\
2020\end{array}$ & \% reduction \\
\hline $\begin{array}{l}\text { Emergency } \\
\text { procedures }\end{array}$ & 331 & 173 & 52.2 \\
$\begin{array}{l}\text { Scheduled } \\
\text { procedures }\end{array}$ & 611 & 136 & 22.2 \\
Total & 942 & 309 & 32.8
\end{tabular}

suspected patients may require an elective procedure that cannot be deferred or an emergency surgery. The current recommendations suggest limiting the number of scheduled surgeries, even in cancer patients, postponing or deferring those cases that do not affect disease progression and only operating those patients with occlusive, infected or bleeding neoplasms. Nevertheless, each case should be thoroughly analyzed $^{2}$. The number of scheduled surgeries in our hospital decreased by almost $80 \%$ according to the current recommendations issued and there were no patients with suspected/confirmed disease scheduled for surgery (136/309, 44\%).

A total of 309 patients were operated on between April and May 2020 (two thirds less than in the same period over the previous year): of these, only $17(9.8 \%)$ were suspected cases and $3(1.7 \%)$ were confirmed cases with positive PCR test and all of them underwent emergency surgery. Previously, all these patients underwent triage for COVID-19 with the corresponding questionnaire, chest computed tomography scan or, in the absence of CT capabilities, a chest X-ray ${ }^{13}$. If possible, surgery should be postponed for a few hours if the patient is not compromised to obtain a specimen for PCR test according to the patient's history and type of procedure, but it is necessary to consider that emergency surgeries should not be delayed to perform a PCR test ${ }^{2}$.

In the hospital surgical area, structural changes were made in the operating rooms and in the circulation of patients, in order to reduce exposure among nonaffected patients and suspected or positive patients, thus reducing the risk of transmission of the disease and ensuring safety of the surgical team and patients ${ }^{14}$.

The surgeon was required to contact the surgical area in advance to inform about the procedure he was going to perform and thus the specific supplies and materials were prepared before patient's arrival. The materials were kept in the entrance hall of the operating room designated for COVID-19 patients.

It is important to emphasize that interventions on suspected or positive COVID-19 patients should always be performed by trained and experienced personnel. These health care professionals must be familiar with the measures to prevent transmission and circulation in restricted areas and with the correct use of PPE. They should have previously participated in simulation protocols to reduce the risk of disease transmission. In addition, experience is essential to shorten the duration of the procedure and decrease the exposure of the entire surgical team.

For this purpose, training in theory and practice is useful, carrying out simulations of preestablished protocols. These simulations are carried out in the institution every day with the entire surgical team (medical and non-medical staff). 
Level 3 PPE should be worn in positive COVID-19 patient surgery ${ }^{6}$. Even in unconfirmed but suspected cases, in the current pandemic setting, all patients are supposed to be positive and the same protective measures are taken to avoid unnecessary exposure of the staff ${ }^{2,8}$. PPE provide complete coverage of the skin, particularly of high-risk areas as the nose, mouth and eyes. Aerosolization can occur in surgical procedures, so PPE should protect against this particular route of transmission ${ }^{6}$.

The two scrub persons assigned to the surgical area prepare the OR bed before patient's arrival. Once prepared, they request to transfer the patient to the established OR using disposable material if possible?

The patient enters the operating room through the established route (see Fig. 1) wearing a surgical mask, hat, gown and gloves under supervision of the circulating nurse. The anesthesia resident or tech assists the anesthesiologist during orotracheal intubation, and once the patient is ventilated, the surgical team is admitted to the OR to begin surgery. Doors should always be kept closed and the number of professionals inside the OR and their displacements should be limited in order to reduce the risk of contamination ${ }^{2}$.

The stretcher-bearer is called when the surgery has finished and the patient is ready to be transported. If the patient will be transferred to the intensive care unit or coronary care unit, the anesthesiologist will doff the gown, gloves and shoe covers in the exit lobby under the supervision and assistance of the circulating nurse and will accompany the patient wearing new PPE.

The circulating nurse is be responsible for checking the exit actions of the surgical team and, for this purpose, a new checklist for safe surgery associated with a patient potentially infected by the coronavirus was designed and implemented. It is not intended to replace the checklist proposed by the $\mathrm{WHO}^{5}$ or the version used since 2010 in the operating rooms of our institution ${ }^{14}$; it is an addendum on the back of the checklist to facilitate its use, with fewer forms and adapted to the current situation ${ }^{9}$.

At the end of the surgery, the OR room is finally cleaned, with a focus on the flat and supporting surfaces. Disinfectants approved to kill viruses are sodium hypochlorite or other chlorides, alcohols, quaternary ammonium compounds and accelerated hydrogen peroxide ${ }^{15}$. Cleaning staff perform their task with appropriate PPE (Level 2$)^{2}$ and they must be trained and participate in the simulation protocols that are carried out every day in the surgical area. After one hour, the OR can be used again.

This disease, currently with high virus circulation in the community of the Buenos Aires Metropolitan Area (AMBA), demands special measures to reduce the possibility of transmission among patients, the exposure of the health care staff and the development of postoperative complications attributable to this pandemic.
1. Wang D, Hu B, Hu C, et al. Clinical Characteristics of 138 Hospitalized Patients with 2019 Novel Coronavirus-Infected Pneumonia in Wuhan, China. JAMA. 2020. Published online ahead of print. doi:10.1001/jama.2020.1585.

2. Balibrea JM, Badia JM, Rubio Pérez I y col. Manejo quirúrgico de pacientes con infección por COVID-19. Recomendaciones de la Asociación Española de Cirujanos. Cir Esp. 2020; 98(5):2519.

3. Organización Mundial de la Salud (OMS). Actualización de la estrategia frente al COVID-19. 14 de abril de 2020. https://www. who.int/docs/default-source/coronaviruse/covid-strategy-update-14april2020pdf.

4. Organización Mundial de la Salud. Preparación y respuesta ante emergencias. Nuevo coronavirus-República de Corea (procedente de China). Brotes epidémicos. 21 de enero de 2020 (https://www. who.int/csr/don/21-january-2020-novel-coronavirus-republic-ofkorea- ex-china/es/, consultado el 11 de febrero de 2020).

5. Manual de aplicación de la lista OMS de verificación de la seguridad de la cirugía 2009: la cirugía segura salva vidas. https://www. who.int/patientsafety/safesurgery/es/

6. Pittet D, Allegranzi B, Boyce J, et al. The World Health Organization Guidelines on Hand Hygiene in Health Care and Their Consensus Recommendations. Infect Control Hosp Epidemiol. 2009; 30:61122.

7. Phin NF, et al. Personal protective equipment in an influenza pandemic: a UK simulation exercise. J Hosp Infection. 2009;71(1):1521.

8. OPS-OMS. Requerimientos para uso de equipos de protección personal (EPP) para el nuevo coronavirus (2019-nCoV) en estable- cimientos de salud. Versión sujeta a revisión (06-02-2020).

9. Ramos AP, de Anton R, Delor SM, Fraiz V, Arribalzaga EB, Sarotto LE. COVID-19: nueva lista de verificación de cirugía segura. JONNPR. 2020; 5(n):nnn-nn. DOI: 10.19230/jonnpr.3728.

10. Ministerio de Salud de la República Argentina. 20/Mayo/2020: Definición y Criterios para caso sospechoso. https://www.argentina.gob.ar.coronavirus-COVID-19.definicion-de-caso

11. Zopatti DE, Ithurralde P, Sosa J, Bernasconi K, Sánchez Gelós D, y Bourbotte J. Informe estadístico COVID-19. Hospital de Clínicas José de San Martín. Dirección de Estadística - Archivo - Internaciones - Egresos. Período 01/03 al 26/05/2020.

12. Coimbra R, Edwards S, Kurihara H, et al. European Society of Trauma and Emergency Surgery (ESTES) recommendations for trauma and emergency surgery preparation during times of COVID-19 infection. Eur J Trauma Emerg Surg (2020). https://doi.org/10.1007/ s00068-020-01364-7.

13. Jimenez Paneque RE. Indicadores de calidad y eficiencia de los servicios hospitalarios: Una mirada actual. Rev Cubana Salud Pública. 2004;30:12-7.

14. Arribalzaga EB, Lupica L, Delor S, Ferraina P. Implementación del listado de verificación de cirugía segura. Rev Argent Cirug. 2012;102(1-3):12-6.

15. https://www.aadinstrumentadores.org.ar/images/paginas/COVID-19/Limpieza_Desinfeccion_Sala_Quirurgica.pdf.pdf

16. Ministerio de Sălud de la Nación Argentina. Recomendaciones generales para Directivos y Jefes de Servicios Hospitalarios. 1/Abril/2020. http://www.msal.gob.ar/images/stories/bes/ graficos/0000001890cnt-covid19-recomendaciones-para-directivos-y-jefes-de-servicio-hospitales.pdf. 